\title{
The Effect of Learning Facilities and Family Environment on Motivation to Learn of Prospective Elementary Teacher Education on Online Learning
}

\author{
Eva Astuti Mulyani ${ }^{1 *}$, Mahmud Alpusari ${ }^{1}$, Elpri Darta Putra ${ }^{2}$ \\ ${ }^{1}$ Departement of Elementary Teacher Education, Faculty of Teacher Training and Education, University of \\ Riau, Pekanbaru Indonesia \\ ${ }^{2}$ Departement of Elementary Teacher Education, Faculty of Teacher Training and Education, Islamic \\ University of Riau, Pekanbaru Indonesia \\ *eva.astuti@lecturer.unri.ac.id
}

Received: November $25^{\text {th }}, 2020$

Revised: January $31^{\text {st }}, 2021$

Accepted: February $07^{\text {th }}, 2021$

\begin{abstract}
This research purpose determines the effect of learning facilities and family environment on motivation to learn of prospective elementary teacher on online learning. The research method used is descriptive quantitative. The data used are primary data obtained directly from filling out a questionnaire by 180 prospective elementary teacher education from a public University, Riau province, Indonesia. The results showed that there was a positive and significant effect of learning facilities and family environment on motivation to learn of prospective elementary teacher in learning during Pandemic, with the results of testing with the $F$ test that obtained an $F$ value of 21.272 with a significance value of $F$ of 0.000 or a sig $F$ value of $<0.05$. The multiple regression test results show that the coefficient of determination (R2) is 0.440 or $44 \%$.
\end{abstract}

Keywords: family environment; learning facilities; learning motivation; online learning.

\section{INTRODUCTION}

The Indonesian government policy is in the form of a Circular of the Minister of Education and Culture of the Republic of Indonesia Number 3 of 2020 concerning the Prevention of Corona Virus Disease (Covid-19) in the Education Unit on March 12, 2020, where lectures carried out by online learning. Follow up government's emergency responses related to the learning process in the form of social comparison as an effort to prevent, contain, or slow down the transmission of the covid-19 virus. Online learning is learning without face to face directly between lecturers and students but done online learning. Online learning is carried out through video conferencing, e-learning, non-e-learning, or distance learning. With online learning, it is expected to realize learning objectives that can be seen, one of which is the output or student learning outcomes. 
One of the most significant things that can affect learning outcomes is motivation in learning (Lestari, Syahrilfuddin, Putra, \& Hermita, 2019; Yuliana, Putra, \& Amtosa, 2020). Motivation change energy for a person to the emergence of feelings and is preceded by responding to a goal (Donald in Sardiman, 2011). Motivation sees as a mental drive that drives and directs human behavior, including learning behavior (Dimyati and Mudjiono, 2010).

The learning process requires the motivation to drive the activities in it. Motivation is essential in determining how many students will be learning from a learning activity or how much to absorb the information presented to them (Riswanto \& Aryani, 2017). Students who have strong motivation will have a lot of energy and enthusiasm to participate in learning activities regardless of their circumstances, both in face-to-face lectures and online learning. In learning activities, motivation becomes a capable driving force giving rise to learning activities and giving direction to learning activities so that the goal can be achieved (Kasdianti, A et al., 2019). Internal and external factors influence motivation to learn. Syamsu Yusuf (2009) states that learning motivation can arise due to internal and external factors. Extrinsic motivation can encourage people around students, such as parents, encouragement from friends, teachers, the community, and other environments (Mulyani et al., 2020). Research is carried out on external student factors, namely learning facilities and family environment. The influence of learning facilities and the learning environment on PGSD FKIP Riau University students' learning motivation in online learning will be seen.

\section{METHODS}

This research uses a quantitative descriptive approach. The descriptive method is defined as a study that describes data factually and objectively. Quantitative research is processing data and obtaining numbers to describe the effect of learning facilities and family environment on student learning motivation. The research was conducted at prospective elementary teacher education, Faculty of Teacher Training and Education, Universitas Riau, with a population of 2018, 2019, and 2020, totaling 360 students.

Determination of the sample from the population was developed from Issac and Michael for an error rate of $5 \%$. If the population is 360 , the sample size is 180 . In this study, the sampling technique used was proportional random sampling, random and proportional or balanced sampling. The list of research samples can be seen in the following Table.

Table 1. List of Research Samples for PGSD Students, FKIP Riau University 


\begin{tabular}{|c|c|c|c|c|}
\hline No & Class & $\begin{array}{l}\text { Population } \\
\text { (Student) }\end{array}$ & $\begin{array}{c}\text { Sample } \\
\text { Calculation }\end{array}$ & Sample \\
\hline 1 & $2018 \mathrm{~A}$ & 40 & $(40 / 360) \times 180$ & 20 \\
\hline 2 & 2018B & 39 & $(39 / 360) \times 180$ & 20 \\
\hline 3 & $2018 C$ & 40 & $(40 / 360) \times 180$ & 20 \\
\hline 4 & $2019 A$ & 40 & $(40 / 360) \times 180$ & 20 \\
\hline 5 & 2019B & 41 & $(41 / 360) \times 180$ & 20 \\
\hline 6 & $2019 C$ & 41 & $(41 / 360) \times 180$ & 20 \\
\hline 7 & $2020 A$ & 40 & $(40 / 360) \times 180$ & 20 \\
\hline 8 & $2020 B$ & 40 & $(40 / 360) \times 180$ & 20 \\
\hline \multirow[t]{2}{*}{9} & $2020 C$ & 39 & $(39 / 360) \times 180$ & 20 \\
\hline & Jumlat & 360 & & 180 \\
\hline
\end{tabular}

The data collection technique used in this study was a questionnaire. This study used a closed questionnaire and an open questionnaire. The following steps made the research instrument:

1. We are creating a research instrument lattice by developing variable learning motivation, learning facilities, and family environment.

2. The score calculation uses a Likert scale with a score of 1-5 (5 = always, $4=$ often, $3=$ ever, 2 = sometimes and $1=$ never) and a table of trends.

Furthermore, the research instrument was tested to determine the level of validity and reliability of the instrument. Arikunto (2006, p.168) said that a suitable instrument must meet two essential requirements: valid and reliable. The trial subjects were taken from 60 students of the 2017 prospective elementary teacher education, Faculty of Teacher Training and Education, Universitas Riau, who were not research samples with the one shoot technique. Test data obtained to determine whether the instrument is suitable for use as a research instrument or not will be tested for validity and reliability testing. The questions were analyzed using SPSS 20.0 for windows.

a. Validation Test

1) The validation test results on the student motivation test statement in the Table above show that of the 23 questions tested, and there were three invalid statements. The correlation value obtained by this question is below the acquisition correlation limit, namely 0.254 . Meanwhile, the other 20 statements were declared valid and were above the correlation value obtained.

2) The validation test results on the learning facility trial's statement in the Table above show that, of the 11 statements tested, all 11 other statements were declared valid and were above the correlation value obtained.

3) The validation test results on the family environment test 
statement in the Table above show three invalid questions of the 19 statements tested. The correlation value obtained by this question is below the acquisition correlation limit, namely 0.254. Meanwhile, the other 16 statements were declared valid and were above the correlation value obtained.

b. Reliability Test

1) Test the reliability of the learning motivation instrument From the results of data processing using SPSS software, obtained a reliability value of 0.719 from 23 items of statements to 60 students. The research instrument was declared reliable, because $\mathrm{r} 11=$ $0.719>0.6$.

2) Test the reliability of the learning facilities instrument From the results of data processing using SPSS software, and the reliability value obtained was 0.862 from 11 items to 60 students. The research instrument was declared reliable, because $r 11=0.862>$ 0.6 .

3) Reliability test of family environment instruments From the results of data processing using SPSS software, the reliability value obtained was 0.873 from 19 items of statements to 60 students. The research instrument was declared reliable, because $r 11=$ $0.873>0.6$.

\section{RESULTS AND DISCUSSION}

\section{Results}

\section{a. Analysis Prerequisite Test}

Before conducting data analysis or testing hypotheses using multiple regression analysis, some requirements must be met: normality test, linearity, multicollinearity, and homosexuality. If these conditions have been met, the analysis can be continued.

1) Normality Test

Table 2. Normality Test Results

\begin{tabular}{lc}
\hline \multicolumn{1}{c}{ Variable } & Value Asym Sig (2-tailed) \\
\hline Learning Motivation & 0,289 \\
Learning Facilities & 0,130 \\
Family Environment & 0,796 \\
\hline
\end{tabular}

The normality test results show that the Asymp Sig value for the learning motivation variable is 0.289 , the learning facility variable is 0.130 , and the family environment variable is 0.796 .
Based on the analysis results, the three variables have an Asymp value of Sig $>0.05$, so all tested data is usually distributed.

2) Linearity Test 
Table 3. Linearity Test Results

\begin{tabular}{lccc}
\hline \multicolumn{2}{c}{ Variable } & & \\
\cline { 1 - 2 } \multicolumn{1}{c}{ Independent } & Dependent & $F_{\text {count }}$ & Sig \\
\hline Learning Facilities & Learning & 1,563 & 0,110 \\
Family Environment & Motivation & 1,573 & 0,107 \\
\hline
\end{tabular}

From the output results in the Table above, it can be seen that the value of $\mathrm{Sig}>=0.05$, it can be concluded that the independent variable and the dependent variable have a linear relationship. In this regression analysis, the linearity requirements are met.

3) Multicollinearity Test

Table. 4 Multikolinearity Test Results

\begin{tabular}{lccl}
\hline \multicolumn{1}{c}{ Variable } & Tolerance & VIF & \multicolumn{1}{c}{ Conclusion } \\
\hline Learning Facilities & 0,785 & 1,274 & Multicollinearity does \\
Family Environment & 0,785 & 1,274 & not occur \\
\hline
\end{tabular}

Based on Table. 4 above, it can be said that the assumption is that there is no tolerance more than 0.1 so that it is free from multicollinearity symptoms and data analysis can be continued.

4) Homosedatisitas Test

Table 5. Homosedatisitas Test Results

\begin{tabular}{lcl}
\hline \multicolumn{1}{c}{ Variable } & Value Sig. & \multicolumn{1}{c}{ Conclusion } \\
\hline Learning Facilities & 0,2491 & Homosedatisitas \\
Family Environment & 0,117 & occurred \\
\hline
\end{tabular}

It can be seen in Table 4.5 above that the significance value (Sig.) The column shows the number of more than 0.05 , so it can be concluded that the regression analysis meets the requirements for homosexuality.

\section{b. Effect of Learning Facilities and Learning Environment on Student Motivation}

In testing the hypothesis, namely: There is a Positive and Significant Effect of Learning Facilities and the Family Environment on Learning Motivation of prospective elementary teacher education in Online Learning Multiple regression analysis hypothesis testing with the following calculation results 
Table 6.s Results of Multiple Regression Analysis

\begin{tabular}{lccc}
\hline \multicolumn{1}{c}{ Variable } & $\begin{array}{c}\text { Coefisien } \\
\text { Regresion (b) }\end{array}$ & t & Sig. \\
\hline Learning Fasilities & 0,071 & 2.909 & 0,004 \\
Family Environment & 0,054 & 3.821 & 0,000 \\
Constanta & 3,243 & & \\
R & 0,440 & & \\
R2 & 0,194 & & \\
F & 21,272 & & \\
Sig. & 0,000 & & \\
\hline
\end{tabular}

Based on the analysis above, the regression line equation for the two predictors is $Y=3.243+0.071 X 1+$ $0.054 X 2$. Table 4.6 shows that the double $R$ coefficient is 0.440 , while $R 2$ is 0.194 . the Table shows that the variance in student learning motivation in online learning can be explained by $44 \%$ of the Learning Facilities and Family Environment through the model, while the rest $(56 \%)$ is explained by other variables that are not taken into account in this model.

The results of the calculation of this hypothesis test, the constant value (b) is 3.243, and the regression line coefficient (b1) is 0.071 , and (b2) is 0.054 positive, it can be concluded that simultaneously the Learning Facilities and Family Environment have a positive influence on student learning motivation in online learning. Significance test obtained from $F_{\text {count }}$ of 21.272 with a significance of 0.000 . Because the significance value is less than 0.05 , it can be said that simultaneously the Learning Facilities and Family Environment have a positive influence on student learning motivation in online learning.

The results of the analysis show that the research hypothesis $(\mathrm{Ho})$ is rejected, and the alternative hypothesis $(\mathrm{Ha})$, which reads "There is a Positive and Significant Effect of Learning Facilities and Family Environment on Learning Motivation of prospective elementary teacher education in Online Learning" is accepted.

\section{Discussion}

The research analysis shows a significant effect of learning facilities and family environment on prospective elementary teacher education learning motivation in online learning. The research shows the test results with the $F$ test, which obtained a $F_{\text {count }}$ of 21.272 with a significance value of $F$ of 0.000 . or the sig value $F<0.05$. Multiple regression testing results show that the coefficient of determination (R2) is 0.440 or $44 \%$. The coefficient of determination shows the useful contribution of the two 
independent variables to the dependent variable. The more students have adequate learning facilities and a right family environment, the higher the learning motivation. The school's role is in providing optimal facilities, and the family's role in giving attention both physically and non-physically can create comfort that will encourage students to learn. Learning facilities and family environment affect learning motivation by $44 \%$, while the remaining $56 \%$ is influenced by other variables not examined in this study. Learning facilities are all items needed in the teaching and learning process both at home and school. So, if students in their learning are supported by facilities, complete learning so that these students will find it easier to use it (Ahmadi. A \& Widodo, S., 2004, p. 88), having complete learning facilities at home will be very important and helpful for children in the learning process (Sukarni \& Prihatni, 2018). Another opinion was also expressed by Dalyono (2001, p.241), saying that the complete learning facilities will help students learn, the lack of learning tools or facilities can hinder their learning progress. Learning facilities are needed to support student learning motivation, especially during online learning; when students feel that their facilities are complete and comfortable, they will have more motivation to learn. The study reinforces previous studies that revealed that there is a significant relationship between learning motivation on student achievement (Daniko, 2012; Siska Eko Mawarsih, 2013), and There is a significant beneficial effect between family environment, school environment, learning discipline as well as the motivation to study the learning achievement (Aminah, 2014).

\section{CONCLUSION}

There is a positive and significant influence of learning facilities and family environment on prospective elementary teacher education, Faculty of Teacher Training and Education, Universitas Riau learning motivation. The research is indicated by the $F_{\text {count }}$ value of 21.272 with a significance value of $F$ of 0.000 . Because of the significant value of $F$ $<0.05$, there is an effect of learning facilities and the family environment on student learning motivation. The coefficient of determination (R2) is 0.440 or $44 \%$. Student learning motivation in online learning can be explained by $44 \%$ of the Learning Facilities and Family Environment through the model, while the rest $(56 \%)$ is explained by other variables that are not taken into account in this model.

\section{REFERENCES}

Ahmadi. A \& Widodo, S. (2004). Psikologi Belajar. Jakarta: PT.Rineka Cipta.

Aminah, I. S. S. ; Y. S. (2014). Pengaruh Lingkungan Keluarga, Lingkungan Sekolah, Disiplin Belajar dan Motivasi Belajar terhadap Prestasi 
Belajar Ekonomi Siswa SMA Kelas XI IPS SMA PGRI 1 Taman Pemalang. Economic Education Analysis Journal, 3(1), 46-51.

Arikunto. S. (2010). Prosedur Penelitian Suatu Pendekatan Praktik. Jakarta : Rineka Cipta

Daniko, P. (2012). Hubungan Antara Pemahaman Materi, Motivasi Belajar, Dan Prestasi Belajar Pada Siswa Kelas VIII SMP Taman Dewasa Ibu Pawiyatan Yogyakarta Tahun 2012. Universitas Ahmad Dahlan Yogyakarta.

Dimyati,M. (2010). Belajar Dan Pembelajaran. Jakarta: PT. Rineka

Kasdianti, A. et al. (2019) Hubungan Motivasi Ekstrinsik Dengan Hasil Belajar Matematika Siswa Kelas V Sd Se-Gugus I Kecamatan Marpoyan Damai Pekanbaru. Jurnal PAJAR (Pendidikan dan Pengajaran). 3(1). 1-5.

Kuntarto, E. (2018). Keefektifan model pembelajaran Daring dalam Perkuliahan Bahasa Indonesia, Journal Indonesian Language Education dan Literature. 3(1). http://www.syekhnurjati.ac.id/jurna l/index.php/jeill/.

Lestari, S., Syahrilfuddin, S., Putra, Z. H., \& Hermita, N. (2019). The Effect of Realistic Mathematic Approach on Students' Learning Motivation. Journal of Teaching and Learning in Elementary Education, 3(2), 145156.

Mulyani, E. A., Kasdianti, A., Ain, S. Q., Alim, J. A., Sari, I. K., \& Alpusari, M. (2020). Correlation between
Elementary School Students' Mathematics Self-Efficacy and Motivation. Journal of Teaching and Learning in Elementary Education, 3(1), 88-94. https://doi.org/10.33578/jtlee.v3i1.7 831

Mustofa, M.I. (2019). Formulasi Model Perkuliahan Daring Sebagai Upaya Menekan Disparitas Kualitas Perguruan Tinggi, Walisongo Journal of Information Technology. $1(2)$.

http://dx.doi.org/10.21580/wjit.201 9.1.2.4067

Ramadhan, R., dkk. (2018). Pengembangan Pembelajaran Bauran (Blended Learning) di Universitas Negeri Jakarta, Jurnal Pembelajaran Inovatif. 1(1), 37-48. DOI : 10.21009/JPI.011.07

Riswanto, A., \& Aryani, S. (2017). Learning motivation and student achievement: description analysis and relationships both. COUNS-EDU: The International Journal of Counseling and Education, 2(1), 42. https://doi.org/10.23916/002017026 010

Siska Eko Mawarsih, D. (2013). Pengaruh Perhatian Orang Tua dan Motivasi Belajar terhadap Presatsi Belajar Siswa SMA Negeri Jumapolo. JUPE UNS, 1(3), 1-13.

Sugiyono. 2013. Metode Penelitian Kuantitatif Kualitatif dan R\&D. Bandung: Alfabeta.

Sukarni, \& Prihatni, Y. (2018). Kontribusi pembelajaran disiplin belajar , fasilitas belajar di rumah, dan 
perhatian orang tua terhadap prestasi siswa ilmu pengetahuan alam The contribution oflearning discipline contributions, home study facilities, and parents attention to student a. Wiyata Dharma: Jurnal Penelitian Dan Evaluasi Pendidikan, 6(1), 92-101.

Sumiati. 2012. Pengaruh Lingkungan Belajar Siswa terhadap Motivasi Belajar dan implikasinya terhadap Hasil Belajar Siswa pada Mata
Pelajaran Ekonomi. Skripsi. Bandung: UPI

Yuliana, Y., Putra, M. J. A., \& Antosa, Z. (2020). Faktor-Faktir yang Mempengaruhi Motivasi Siswa Sekolah Dasar dalam Mengikuti Aktivitas Pramuka Penggalang. Tunjuk Ajar: Jurnal Penelitian IImu Pendidikan, 3(2), 210-226.

Yusuf, S. (2009). Program Bimbingan dan Konseling di Sekolah. Bandung: Rizqi Perss. 